Горват Т. Ю., аспірантка

Західноукраӥнський національний університет

м. Тернопіль, Украӥна

DOI: https://doi.org/10.30525/978-9934-26-107-7-18

\title{
ПІДХОДИ ДО КЛАСИФІКАЦЇ̈ ФОРМ ДЕРЖАВНОГО РЕГУЛЮВАННЯ ЕКОНОМІКИ
}

Цивілізована держава, що стоїть на шляху фундаментальних реформ та невпинного розвитку в умовах функціонування ринкової економіки, тобто застосовує основні елементи ринкового механізму саморегулювання, серед яких можна виділити, зокрема, попит, пропозицію, конкуренцію та ціну, повинна враховувати всі ключові засади та принципи такого спрямування економіки. Основою системних ринкових реформ $є$ запровадження державою механізмів, здатних забезпечити об'єктивні та справедливі економічні відносини, рівні можливості, умови та права для усіх учасників ринку.

В окремих випадках, необхідність впливу та втручання держави в економічні процеси є виправданим та безсумнівним, адже від розвитку економіки залежить і розвиток самої держави. Саме тому вона повинна «тримати під контролем» значущі фактори впливу на економіку та вживати всі необхідні заходи для ii стабільного функціонування. Це стосується, насамперед, випадків, коли спостерігається очевидна незлагодженість у діяльності ринку, тобто дії ринку не є достатньо ефективними. Однак, вкрай важливим в управлінні економікою $є$ адекватне співвідношення між впливом ринку, як базового регулятора економічних відносин та безпосередньо держави, прагненням якої $\epsilon$, передусім, налагодження економічних процесів.

За роки незалежності, розбудови національної економіки та системних перетворень економічних відносин в Україні вплив держави на соціально-економічний розвиток досліджували багато науковців. Ними була сформована певна система основних методів, форм та інструментів, що використовуються державою 
при здійсненні регулювання соціально-економічних процесів. Використання тих чи інших форм, методів та інструментів залежить від економічної стратегії держави, іiі матеріальноресурсних потужностей тощо.

Однак, слід зазначити, що у економічній літературі, автори не дотримуються єдиної класифікації та розмежовування форм, як власне i методів, державного регулювання економіки. Це стосується як відмінностей у їх визначенні, поділі, так і у віднесенні до різних класифікацій.

Формами державного регулювання економіки, на думку Сенишин О.С., є здатні до практичної реалізації прояви державно-управлінської діяльності, тобто засоби, спрямовані на реалізацію цілей для забезпечення регулюючого державного впливу [2, с. 30].

Серед інших, в даній роботі розглянемо підходи кількох науковців до класифікації форм державного регулювання економіки.

Так, Стельмащук А.М. зазначає, що держава використовує різні форми у процесі здійснення регулювання, які можна класифікувати залежно від того чи іншого характеру впливу.

Наприклад, згідно строковості державне регулювання може бути:

- довгостроковим, що спрямоване на досягнення довготривалих, стратегічних цілей;

- короткостроковим, або поточним, що характеризується антициклічним, оперативним (не запланованим заздалегідь) регулюванням, що націлене на швидке реагування при виникненні кризових явищ у економіці [3, с. 29].

Згідно характеру впливу на господарські суб'єкти державне регулювання економіки може бути:

- прямим, що характеризується впливом держави на економічні процеси за допомогою застосування певних регуляторів та адміністративних важелів, націлених на відповідні завдання та обмеження діяльності господарюючих суб'єктів; 
- непрямим, що характеризується впливом держави на господарську діяльність за допомогою застосування необхідних змін в умови функціонування ринкового механізму, використовуючи правові та економічні інструменти [3, с. 29].

Вищенаведена структура форм здійснення державного регулювання наведена на рис. 1.

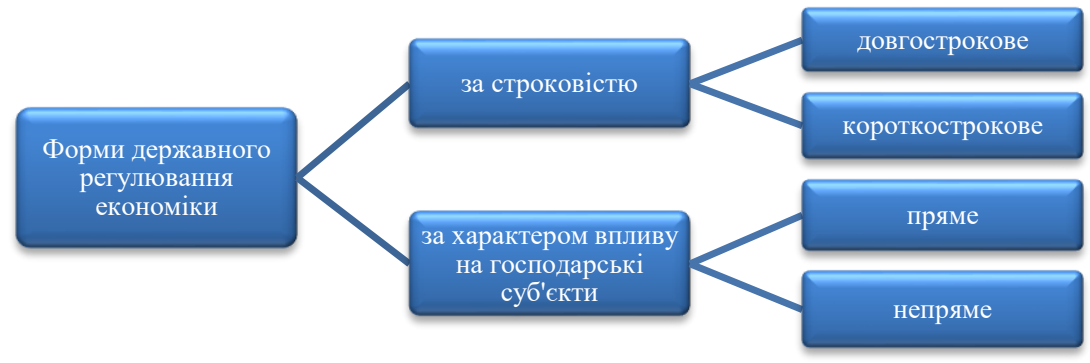

Рис. 1. Форми державного регулювання економіки (за класифікацісю А.М. Стельмащука)

Джерело: систематизовано автором з використанням [3]

Мочерний С.В. та Довбенко М. В. демонструють інший підхід до класифікації форм державного регулювання економіки. Автори вирізняють наступні його форми:

- планування, що в свою чергу поділяється на довготермінове, середньотермінове і короткотермінове. Сутність цієї форми регулювання залежить від рівня економічної системи. На макроекономічному рівні планування передбачає визначення цілей, розробку та реалізацію планів та стратегій, опираючись на економічні закони. На мікроекономічному рівні планування націлене на розробку бізнес-планів, оперативних, короткотермінових цілей. Автори також визначають додаткову подальшу класифікацію планування як форми державного регулювання та визначають такі його окремі форми як: директивне, індикативне та стратегічне;

- програмування, що спрямоване на грунтовний аналіз стану економіки, розробку та реалізацію стратегічних завдань, а також 
виявлення ключових проблем, які не піддаються коригуванню та вирішенню ринковими важелями;

- прогнозування, що скероване на передбачення майбутніх тенденцій зростання економіки [1].

Структура форм державного регулювання, запропонована Мочерним С.В. та Довбенко М.В., наведена на рис. 2.

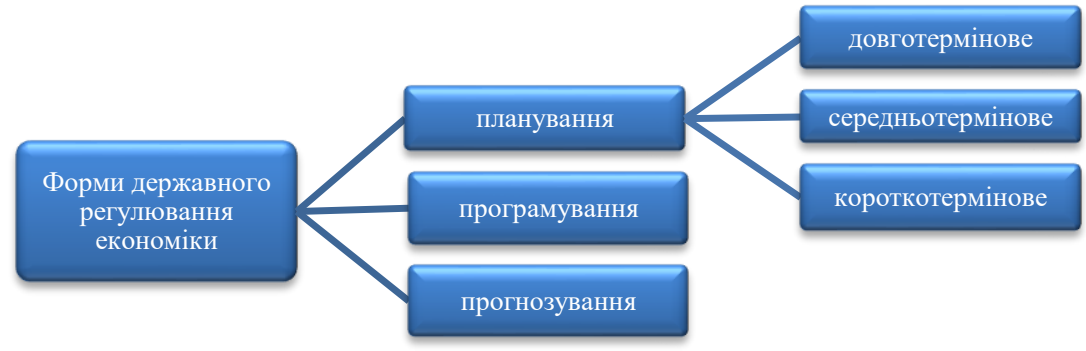

Рис. 2. Форми державного регулювання економіки
(за класифікацісю Мочерного С.В. та Довбенко М. В.)

Джерело: систематизовано автором з використанням [1]

Сенишин О.С. підкреслює, що форми державного регулювання економіки обумовлені соціально-економічними потребами, загальним рівнем розвитку, а також ключовими пріоритетами країни та класифікує їх наступним чином:

- державне замовлення (державний контракт);

- державне прогнозування;

- макроекономічне планування;

- державне програмування [2, с. 31].

Структура форм державного регулювання економіки, класифікована Сенишин О.С., наведена на рис. 3.

Підсумовуючи вищенаведене, можемо резюмувати, що, незважаючи на відмінності у поглядах науковців щодо класифікації форм державного регулювання економіки, а також відсутності чіткої узгодженості щодо їх визначення загалом, ключовий зміст всіх запропонованих форм залишається сталим вони $є$ певними засобами державного впливу та втручання в 
економіку 3 метою соціально-економічного процвітання та розвитку.

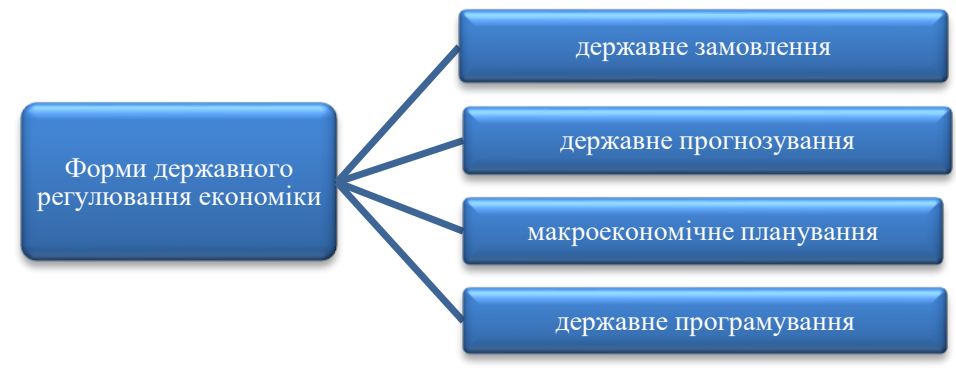

\section{Рис. 3. Форми державного регулювання економіки (за класифікацісю Сенишин О.С.)}

Джерело: систематизовано автором з використанням [2]

\section{Література:}

1. Мочерний С. В., Довбенко М. В. Економічна теорія: Підручник. Київ : Видавничий центр «Академія», 2004. 856 c. URL: https://pidru4niki.com/ 19991130/ekonomika/ekonomichna_teoriya.

2. Сенишин О.С. Державне регулювання економіки : навч. посібник. О.С. Сенишин, М.О. Горинь, О.О. Кундицький. Львів : Львівський національний університет імені Івана Франка, 2014. 334 с.

3. Стельмащук А.М. Державне регулювання економіки : навчальний посібник. Тернопіль, ТАНГ, 2000. 315 с. 